Matti Kummu, X. X. Lu, Akchousanh Rasphone, Juha Sarkkula, and Jorma Koponen. 2008. Riverbank changes along the Mekong River: Remote sensing detection in the Vientiane-Nong Khai area. Quaternary International, volume 186, number 1, pages 100-112.

(C) 2007 Elsevier Science

Reprinted with permission from Elsevier. 


\title{
Riverbank changes along the Mekong River: Remote sensing detection in the Vientiane-Nong Khai area
}

\author{
Matti Kummu ${ }^{\mathrm{a}, *}$, X.X. Lu ${ }^{\mathrm{b}}$, Akchousanh Rasphone ${ }^{\mathrm{c}}$, Juha Sarkkula ${ }^{\mathrm{d}}$, Jorma Koponen ${ }^{\mathrm{e}}$ \\ ${ }^{a}$ Water Resources Laboratory, Helsinki University of Technology (TKK), P.O. Box 5200, FIN-02015 HUT, Finland \\ ${ }^{\mathrm{b}}$ Department of Geography, National University of Singapore, Singapore 119260, Singapore \\ ${ }^{\mathrm{c}}$ National University of Laos (NUoL), Vientiane, Lao PDR \\ ${ }^{\mathrm{d}}$ Finnish Environment Institute (SYKE), P.O. Box 140, FIN-00251 Helsinki, Finland \\ ${ }^{\mathrm{e}}$ Environmental Impact Assessment Centre of Finland (EIA Ltd.), Tekniikantie 21b, 02150 Espoo, Finland
}

Available online 25 October 2007

\begin{abstract}
Riverbank erosion is a natural process, but often human activities can have a significant impact on the rates of morphological change. This paper aims to assess bank erosion problems in the Vientiane-Nong Khai section of the Mekong River, where the Mekong borders Thailand and Lao PDR. The study provides new and more accurate information about recent riverbank movement rates. The bank movement rates are quantified using two Hydrographic Atlases dated 1961 and 1992, derived originally from aerial photos and a field survey, and SPOT5 satellite images acquired on 4 December 2004 and 28 April 2005 with a resolution of $2.5 \mathrm{~m}$ in natural colours. Bank erosion and accretion rates on the left (Lao PDR) and right (Thailand) banks of the Mekong are analysed for two time periods: 1961-1992 and 1992-2005, respectively. The quantified average bank erosion rates were found to be slow, ranging from 0.8 to $1.0 \mathrm{~m} / \mathrm{a}$ for the first and second analysis period, respectively. These average annual erosion rates are only $0.1 \%$ of the channel width, which is very low on a global scale. However, erosion rates were much higher for the islands in the river, 2.4 and $4.8 \mathrm{~m} / \mathrm{a}$ for the two time periods. The quantified accretion for the main banks was $0.4 \mathrm{~m} / \mathrm{a}$ during 1961-1992 and $0.7 \mathrm{~m} / \mathrm{a}$ during 1992-2005, which for the islands increased from 0.6 to $6.4 \mathrm{~m} / \mathrm{a}$ from the first to the second period.
\end{abstract}

(C) 2007 Elsevier Ltd and INQUA. All rights reserved.

\section{Introduction}

River channel changes, such as bank erosion, downcutting and bank accretion, are natural processes for an alluvial river. However, developments like sand mining, infrastructure building on the riverbank, artificial cutoffs, bank revetment, construction of reservoirs and land use alterations have changed the natural geomorphological dynamics of rivers (Lane and Richards, 1997; Surian, 1999; Fuller et al., 2003; Rinaldi, 2003; Li et al., 2007). As a consequence, channel stability is often threatened (Fuller et al., 2003; Grant et al., 2003; Kesel, 2003; Rinaldi, 2003). Such human activities could be stronger forces for change than natural events such as floods, droughts and landslides (Surian and Rinaldi, 2003). These human-induced channel changes may result in various environmental and social-

\footnotetext{
*Corresponding author. Fax: + 35894513827.

E-mail address: matti.kummu@iki.fi (M. Kummu).
}

economic consequences in navigation, loss of riparian land and infrastructure, flood hazard and the alteration of aquatic and riparian ecosystems. Therefore, a better understanding on river channel changes is of great importance for river engineering and environmental management.

In the Lower Mekong Basin (LMB), i.e. the Mekong basin downstream of China and Myanmar, the river is characterised by large areas of alluvial channel (Gupta and Liew, 2007). The whole Upper Mekong Basin and parts of LMB are categorised as rock-cut channel. It has been reported that bank erosion has become a serious problem for many sites along the lower Mekong River in terms of imperilling nearby settlements and infrastructure (e.g. Pham et al., 2004; Le et al., 2006). Recent damages caused by bank erosion in the Mekong region have been frequently reported. For example, in the lower Mekong delta of Vietnam alone tens of lives were lost, six villages with 2200 houses were eroded and damaged, and numerous 
infrastructure such as bridges, roads, ports and buildings, etc. were destroyed in recent decades (Le et al., 2006). In the Lower Mekong Basin, the impact of bank erosion on humans is a serious problem.

Bank erosion, island growth and attachment of islands to riverbanks are also sensitive transboundary issues as the Mekong River forms a significant length of the border between Lao PDR and Thailand. River channel changes therefore have implications for the position and administration of the border line (Rutherfurd et al., 1996). Especially, it has been reported that the Vientiane-Nong Khai section of the border between the two countries has experienced an increasing bank erosion problem (JICA, 2004). The area has long had a reputation as being one of the most unstable reaches of the river (Rutherfurd et al., 1996). According to Rutherfurd et al. (1996), the average erosion rate was $0.7 \mathrm{~m} / \mathrm{a}$ during 1959/1961-1988. However, on a global scale this is one magnitude lower than many other large rivers (Van de Wiel, 2003).

This study focuses on this trans-national part of the Mekong in order to assess the above problems and provide information on bank movement rates. The study aims to: (1) assess how much the shape of the river in the Vientiane-Nong Khai section has changed over time as a result of bank movement; (2) discuss the possible causes of the changes in bank erosion rates, especially over the latest 10 years or so; and (3) compare the study section erosion rates to global erosion rates. The paper focuses on assessing changes in bank location by remote sensing. The hydrodynamic EIA 3D Model has been applied to the study area (MRC/WUP-FIN, 2006) but is not presented in more detail in this paper. The social impacts of the bank erosion in Lao PDR side of the study area have also been covered in MRC/WUP-FIN (2006).

\section{Study area}

\subsection{Mekong River}

Carrying an average $475 \mathrm{~km}^{3}$ of water each year from a basin of $795,000 \mathrm{~km}^{2}$, the Mekong is the world's eighth largest river (Mekong River Commission, 2003; Campbell, 2005). The Mekong originates from China and flows through Myanmar, Lao PDR, Thailand, Cambodia and Vietnam before ending in the South China Sea. The annual monsoon climate dominates the hydrology of the Mekong. The discharge varies greatly between dry and wet seasons, being largest during August-September and smallest in April-May (Mekong River Commission 2005; Kummu and Varis, 2007).

Within the study reach the Mekong River has a slightly sinuous channel planform in accord with the definitions of Leopold and Wolman (1957, p. 60) and Dury (1969, Fig. 9.II.5). In the study area, the channel is divided into two channels of unequal cross-sectional area separated by large permanent islands that are not flooded significantly during the annual high-flow, and which sustain relict mature forest and seasonal agriculture. Most of the islands are elongated. The local presence of multiple channels separated by large islands is typical for an incipient anastomosed channel pattern in a sand-bedded tropical monsoon river and accords with Nanson and Knighton's (1996) Type 2 anastomosed rivers.

\subsection{Vientiane-Nong Khai section of the Mekong}

The study area is located in the Vientiane-Nong Khai section of the Mekong River, which forms the border between Thailand and Lao PDR (Fig. 1). An overview of the history of the border and agreements between Thailand and Lao PDR is given by Rutherfurd et al. (1996). This section of the river has experienced increasing riverbank erosion over the past years (JICA, 2004) and has been reported to be one of the most unstable reaches of the river being located immediately below the gorge track of the river (Rutherfurd et al., 1996). Gupta and Liew (2007) classified the Mekong altogether into eight River Units based on the geomorphological characteristic of each section. Our study section falls into the River Unit 2a: "Alluvial channel with visible sediment in low flow". The change from "Upper rock-cut channel, wide channel with sediment" (Unit 1d) to Unit 2a occurs just upstream from the study section.

The total length of the studied river section is $49 \mathrm{~km}$ and is located between 1544 and $1593 \mathrm{~km}$ (kilometres from the mouth of the Mekong in Vietnam). The discharge varies annually from 800 to $14,000 \mathrm{~m}^{3} / \mathrm{s}$, while the total suspended solids (TSS) concentration varies between 50 and $700 \mathrm{mg} / 1$, being highest during August-September as illustrated in Fig. 2 (Kummu and Varis, 2007).

The data used for the analysis of suspended sediment concentration (SSC) and total suspended solids concentration and fluxes in the Mekong mainstream are from the Mekong River Commission's (MRC) databases (Mekong River Commission, 2004). Vientiane station is part of the MRC Water Quality Monitor Network (WQMN), while Nong Khai data is available in the MRC hydrological database (HYMOS) (Kummu and Varis, 2007). The monthly water discharge and suspended sediment concentration averaged from 1993 to 2000 at Vientiane and Nong Khai are also presented in Fig. 2.

\section{Data and materials}

A number of datasets are needed in order to quantify the riverbank changes. The main datasets used in this study are presented below. All spatial data are projected to UTM Zone 48 and use Indian 1960 datum.

The Hydrographic Atlas of 1961, based on a field survey and aerial photos from 1959 to 1961 (Mekong River Commission, 1961), was used to map the bank location in 1961. The scale of the atlas is 1:20,000. The atlas is available only in hardcopy format (Fig. 3). 


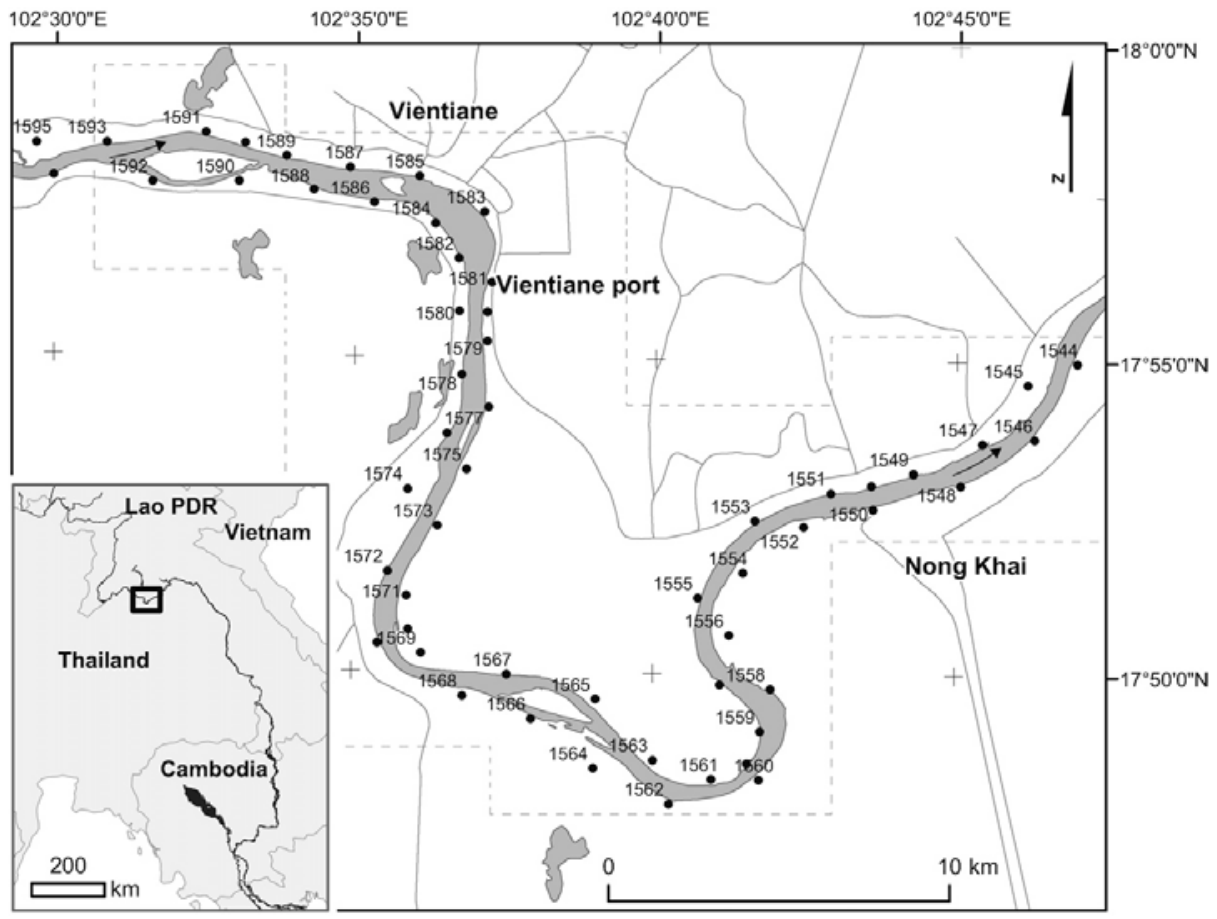

Fig. 1. Map of the study area and its location in larger scale.

The Hydrographic Atlas of 1992, based on field survey (1989-1992) and aerial photos (1991-1992) (Mekong River Commission, 1992), was used to map the bank location in 1992. The scale of the atlas is also $1: 20,000$. The atlas is available in both hard copy and digital format. The digital format used in this study includes riverbank location, islands, land area, and other water features such as tributaries and ponds close to the mainstream (Fig. 4).

Two sets of aerial photos of the 1991/1992 for parts of the Mekong River in Vientiane-Nong Khai area, which were used for preparing the Hydrographic Atlas of 1992, were used in this study to verify the accuracy of the riverbank locations in the Hydrographic Atlas of 1992 digital version.

Rectified SPOT5 satellite images acquired on 4 December 2004 (referred to here as SPOT5 of 12/2004) and 28 April 2005 (SPOT5 of 04/2005) with $2.5 \mathrm{~m}$ resolution in natural colours (Fig. 5) were used to map the bank location in 2005.

The GIS data for the background maps and supportive layers for the main datasets and results illustrations, as country boundaries, roads, rivers, are obtained from MRC spatial database (Mekong River Commission, 2006).

\section{Methods}

\subsection{Data processing}

The following steps were undertaken for the non-digital data, and the data which were not geo-referenced: georeferencing satellite imageries and the scanned Hydrographic Atlas of 1961, digitising the riverbank location of different years using the scanned and satellite images as base maps. The processes used for each dataset are described below in more detail.

\subsubsection{Hydrographic Atlas of 1961}

The scanned Hydrographic Atlas images are illustrated in Fig. 3. Geo-referencing was performed one image at a time for the Vientiane control point layer of 1992. The Vientiane-Nong Khai road layer of 1992 could not be used in this process due to various changes in the road network over time. A first order transformation was used for geo-referencing all the images, with an average RMS (root mean square) error of 1.4 (i.e. the mean accuracy is $\pm 1.4 \mathrm{~m}$ ). The riverbank location was then converted into a new shape file (*.shp) used in most GIS softwares. 

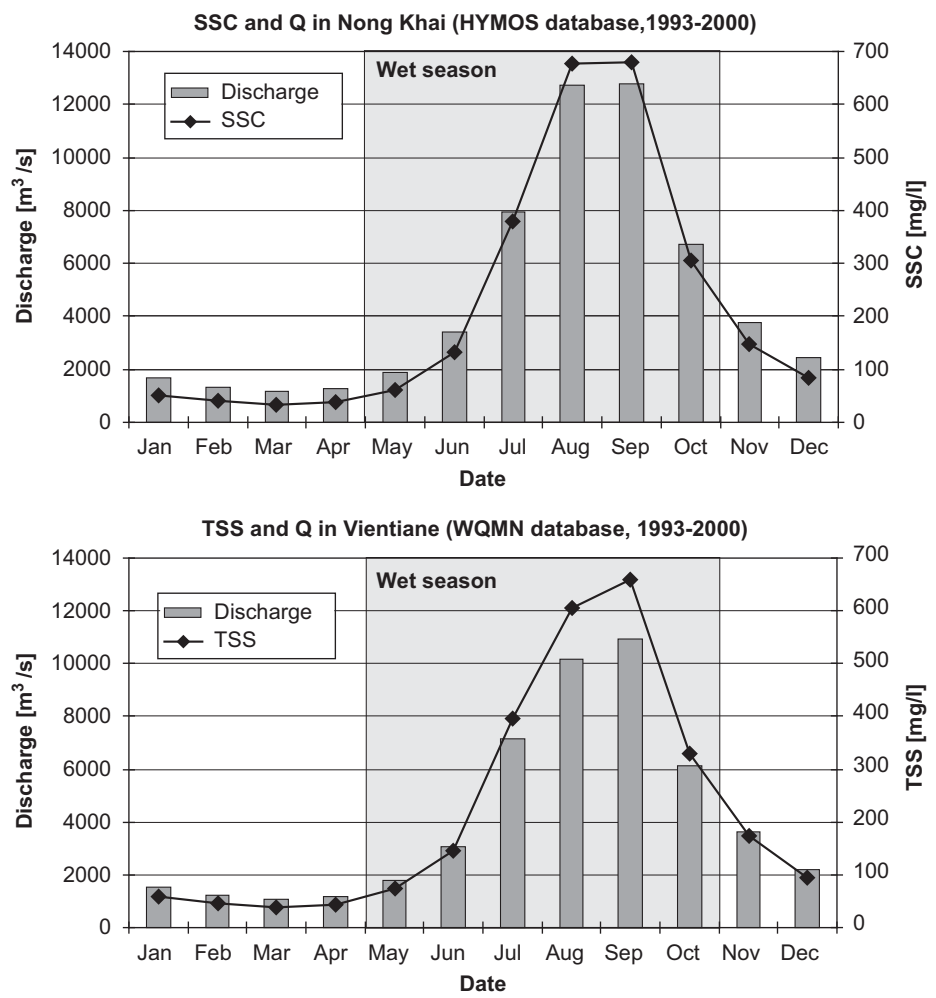

Fig. 2. Monthly averages for SSC concentration and discharge (1993-2000) in Vientiane and Nong Khai (modified from Kummu and Varis, 2007).

\subsubsection{Hydrographic Atlas of 1992}

The Hydrographic Atlas of 1992 was already in a digital format. Before the analysis phase was carried out, the accuracy of the digital atlas was checked against the 1991/1992 aerial photos of the same area. Two available aerial photos were geo-referenced to the 1992 road layer using first order transformation. Four control points were identified for this process. The average RMS error of the geo-referencing is 2.6 (i.e. the transformation is accurate to $\pm 2.6 \mathrm{~m}$ ). After superimposing the 1992 riverbank location onto the aerial photos, it was found that the boundary of riverbank aligned with an average error of $1-2 \mathrm{~m}$ in relation to the riverbank presented on the photos.

\subsubsection{SPOT5 satellite images}

SPOT5 images of $12 / 2004$ and $04 / 2005$ with $2.5 \mathrm{~m}$ resolution are presented in Fig. 5. The 04/2005 image was used for most of the area while the 12/2004 image was used only for the most western parts, which were not covered by the $04 / 2005$ image. The riverbank location, sandbars and islands were digitised from the SPOT5 images. Fig. 5 illustrates also a close-up of the western part of the image.

\subsection{Data analysis}

In the analysis, the riverbank location from the three different datasets, presented above, were compared by using the ArcGIS 8.3 software and its extensions. The comparison of the riverbank location was carried out in the two phases, 1961-1992 (31 years) and 1992-2005 (13 years), for both the riverbanks and the islands. This analysis was made in order to measure the changes in riverbank location that have occurred over time and to identify the places where erosion and accretion occurred in each specific time period. The riverbank erosion and accretion were calculated separately for each side of the riverbanks and the islands. The results are presented spatially by mapping the erosion areas, and with a graph where the bank movement rates are plotted as a function of distance (each kilometre) along the banks.

As in any GIS and remote sensing work, the possible inaccuracy of our results are inherited from both local and positional errors, as a result of employing maps obtained in various times and with various scales. Therefore, changes in bank location of less than about $4 \mathrm{~m}$, or $0.13 \mathrm{~m} / \mathrm{a}$, for the 1961-1992 period, and less than about $5 \mathrm{~m}$, or $0.38 \mathrm{~m} / \mathrm{a}$, for 


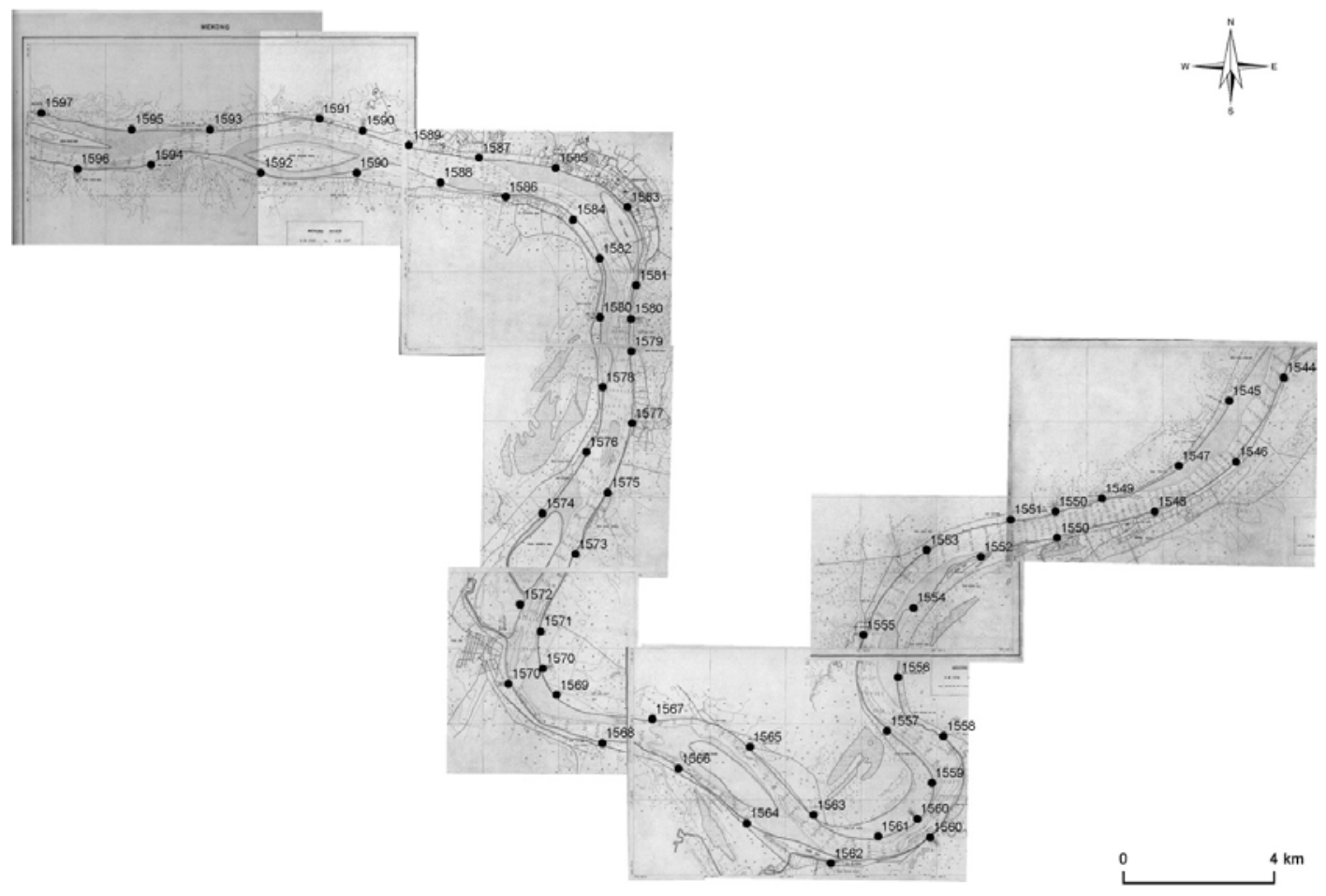

Fig. 3. Scanned Hydrographic Atlas images of 1961 after geo-referencing to digitalised control points in Vientiane-Nong Khai in 1992.

the 1992-2005 period are not detectable given the resolution of the various digital data resources used in the analysis.

\section{Results}

\subsection{Riverbank changes from 1961 to 1992}

The riverbank location changes during the period 1961-1992 are presented in Fig. 6. The average bank erosion rate for the study area was $0.8 \mathrm{~m} / \mathrm{a}$. The erosion rates were 0.7 and $0.9 \mathrm{~m} / \mathrm{a}$ for the left (Lao PDR) and right (Thailand) banks, respectively (Table 1). The bank accretion was similar for both banks, around $0.4 \mathrm{~m} / \mathrm{a}$ on average.

The rates of bank movement as a function of distance along the left and right banks are plotted in Fig. 7. The high variability in the spatial pattern of the erosion can be seen from the graph. As can be observed from Figs. 6 and 7 , erosion occurred in a large area, especially nearby $1568 \mathrm{~km}$, on the left bank side. On the right bank, $1578 \mathrm{~km}$ suffered from serious erosion, which might be related to the movement of the sandbar. Considerable bank accretion occurred in a large area between 1574 and $1576 \mathrm{~km}$ on the left bank. Accretion appeared nearby $1553 \mathrm{~km}$ on the right bank, but its cause is not clear. Another place where bank accretion occurred was between 1572 and $1574 \mathrm{~km}$.

Rutherfurd et al. (1996) made a similar study using the 1961 and 1992 hydrographic atlases to estimate the bank erosion and accretion rates in the Vientiane-Nong Khai reach of the Mekong. They used the name "1988 hydrographic survey" for the Hydrographic Atlas of 1992. Rutherfurd et al. (1996) calculated the net loss of land (erosion minus deposition) arriving at $5 \mathrm{ha} / \mathrm{a}$ in the left bank and $1.4 \mathrm{ha} / \mathrm{a}$ in the right bank. Our results for net loss of land are $1.4 \mathrm{ha} / \mathrm{a}$ for the left and $2.4 \mathrm{ha} / \mathrm{a}$ for the right bank. Thus, the results differ greatly on the left bank, but are similar on the right bank, though the results are not directly comparable due to the different analysis methods.

\subsection{Riverbank changes from 1992 to 2005}

The riverbank location changes during the period 1992-2005 are presented in Figs. 8 and 9. During this period of 13 years, the calculated average bank erosion rate for the study area was $1.0 \mathrm{~m} / \mathrm{a}$. The rate was $1.2 \mathrm{~m} / \mathrm{a}$ for the left bank and $0.8 \mathrm{~m} / \mathrm{a}$ for the right bank (Table 2). The average bank accretion rate was $0.7 \mathrm{~m} / \mathrm{a}$ for the whole study area, being $0.6 \mathrm{~m} / \mathrm{a}$ on the left bank and $0.8 \mathrm{~m} / \mathrm{a}$ on the right bank. 


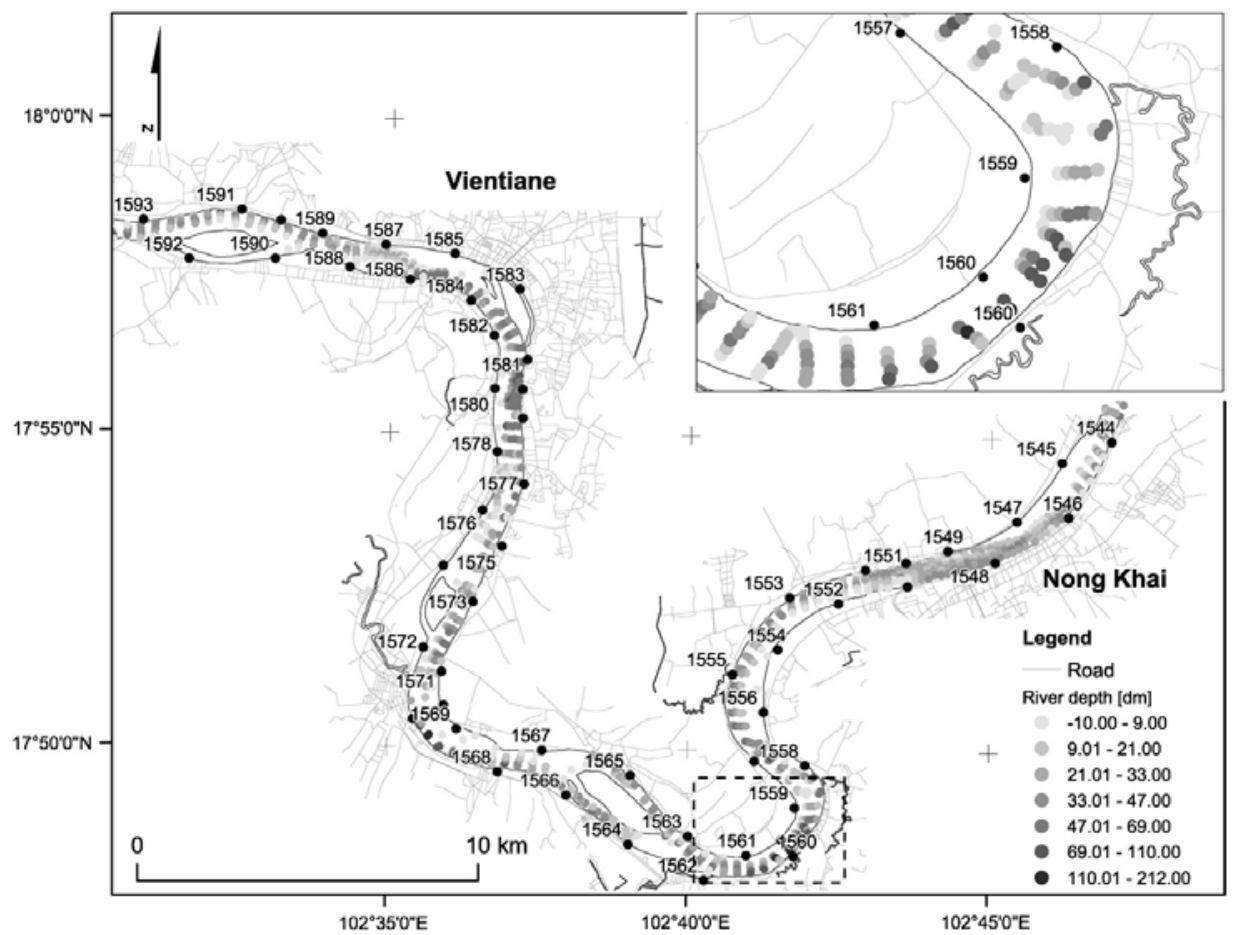

Fig. 4. Hydrographic Atlas data of 1992 for the study area showing the river area, islands, road network, river km-points, and river depth below the lowest low water level (dm).

Compared to the previous period (1961-1992), the erosion rate has dropped slightly $(-8 \%)$ on the right bank (from 0.9 to $0.8 \mathrm{~m} / \mathrm{a}$ ), while it has increased on the left bank by $71 \%$ (from 0.7 to $1.2 \mathrm{~m} / \mathrm{a}$ ). The bank erosion rate of the whole study area increased by $26 \%$, while the bank accretion increased by $75 \%$ from the first analysis period.

The rates of bank movement as a function of distance along each of the left and right banks are plotted in Fig. 10. The high variability in the spatial erosion pattern of the erosion can be seen from the graph. Comparing the results from the first analysis period (Fig. 7) to the latter one, it can be seen that the instability of the bank location has increased throughout the study section. Bank erosion on the left bank occurred along the area between 1571 and $1573 \mathrm{~km}$. One of the remarkable areas of erosion is seen between 1563 and $1566 \mathrm{~km}$, and around 1568 and $1555 \mathrm{~km}$. There are less areas of erosion along the right bank side compared to the left. This is probably due to the increased bank protection work on the Thai side. The protected areas on both sides are illustrated in Fig. 9. Remarkable bank accretion occurred between 1557 and $1559 \mathrm{~km}$ and in $1567 \mathrm{~km}$ on the left bank side. On the right bank side accretion occurred in various locations. The most remarkable area was around 1571 and $1588 \mathrm{~km}$.
The locations of detected bank erosion correspond rather well with the erosion map produced by the WAD (Waterway Administrator Division), Laos (JICA, 2004). This work illustrates that different categories of erosion occurred in the areas along riverbank, based on observations made during field visits and on interviews of the local villagers by the WAD staff.

\subsection{Changes in the Islands}

The results of the changes in the islands are presented in Table 2. The annual erosion of the islands was 2.4 and $4.8 \mathrm{~m} / \mathrm{a}$ for the periods 1961-1992 and 1992-2005, respectively. Hence, the erosion rate has been doubled over the studied periods. The accretion has increased from $0.6 \mathrm{~m} / \mathrm{a}$ during the $1961-1992$ period to $6.4 \mathrm{~m} / \mathrm{a}$ during the latter period. This is, however, partly due to the fact that one of the main islands joined to mainland of the left bank side close to Vientiane. The average erosion rate of the islands for both periods was $3.6 \mathrm{~m} / \mathrm{a}$ while along the shore it was $0.9 \mathrm{~m} / \mathrm{a}$. This is consistent with the figures by Rutherfurd et al. (1996) that the banks of the islands were more unstable compared to the mainland. 


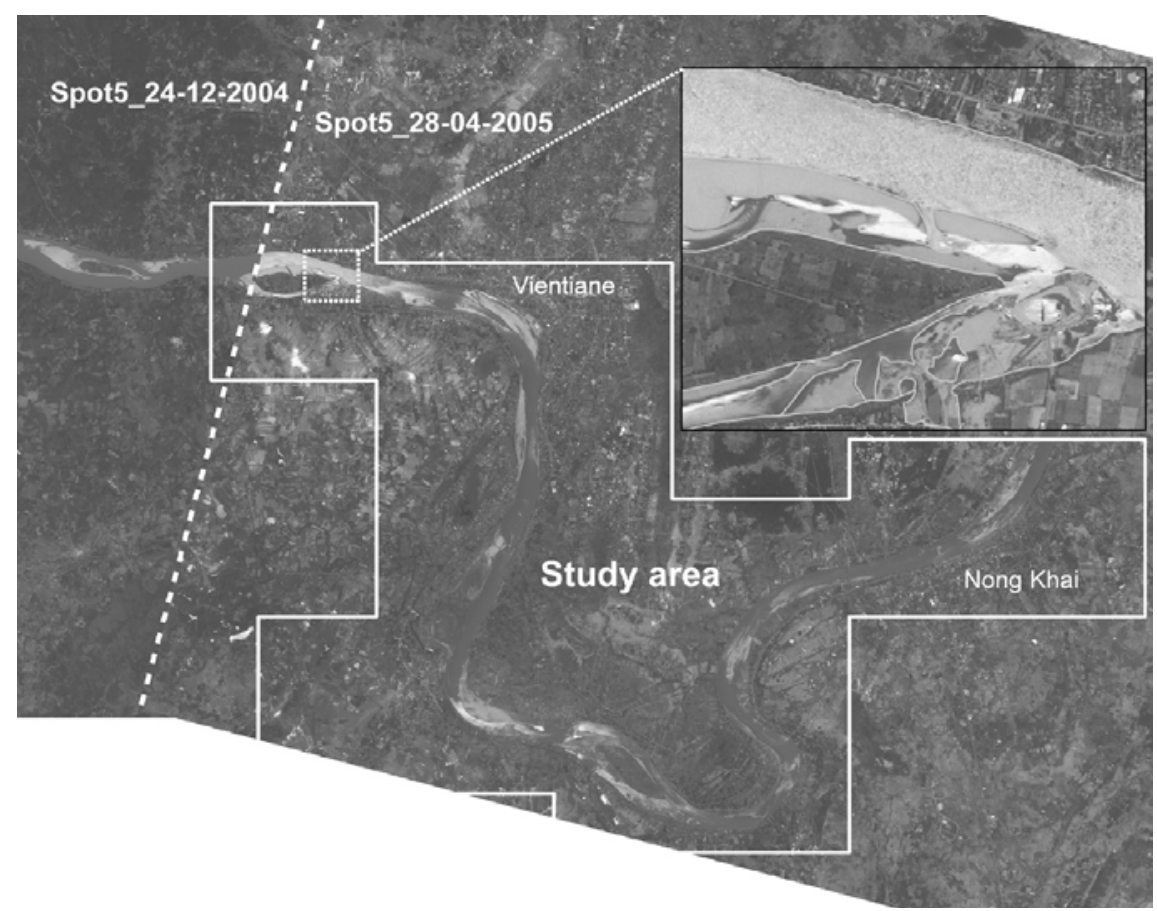

Fig. 5. Areas for SPOT5 images and close-up to the SPOT5 image digitising.

Table 1

Annual average bank erosion and accretion rates $(\mathrm{m} / \mathrm{a})$ for the periods 1961-1992 and 1992-2005. Erosion and accretion rates have been analysed separately for the left and right banks of the river

\begin{tabular}{|c|c|c|c|c|}
\hline & \multicolumn{4}{|c|}{ Annual bank movement (m/a) } \\
\hline & \multicolumn{2}{|c|}{ 1961-1992 } & \multicolumn{2}{|c|}{$1992-2005$} \\
\hline & Left & Right & Left & Right \\
\hline Erosion & 0.7 & 0.9 & 1.2 & 0.8 \\
\hline Accretion & 0.4 & 0.4 & 0.6 & 0.8 \\
\hline
\end{tabular}

\subsection{Global erosion rates}

The catchment size of the Mekong Basin at Vientiane is $299,000 \mathrm{~km}^{2}$ (Mekong River Commission, 2005). Van de Wiel (2003, p. 45) has used 221 observations from a wide range of rivers from around the world to construct the bank erosion rate $(E)$ as a function of the drainage area $(A)$. The best fit regression line for that data is $E=0.053 A^{0.44}$ (ibid). By using the equation developed by Van de Wiel, the average erosion rate for the VientianeNong Khai section of the Mekong would be $12.1 \mathrm{~m} / \mathrm{a}$. Thus, the observed erosion rates, being on average $0.9 \mathrm{~m} / \mathrm{a}$ for the total study period, are around one order of magnitude lower than the global average bank erosion rates for a location with a catchment of that size. The bank erosion rate in our study section in comparison to data collected by Van de Wiel is presented in Fig. 11.

\section{Discussion}

\subsection{Impact of bank protection}

The bank erosion rates have moderately changed when compared between the study periods 1961-1992 and 1992-2005. The average annual erosion rates have barely changed from 0.9 to $0.8 \mathrm{~m} / \mathrm{a}$ for the right bank, but have increased from 0.7 to $1.2 \mathrm{~m} / \mathrm{a}$ for the left bank side. The annual bank accretion rate has increased remarkably on both sides, from 0.4 to $0.6 \mathrm{~m} / \mathrm{a}$ on the left bank and from 0.4 to $0.8 \mathrm{~m} / \mathrm{a}$ on the right bank. This might partly be the result of the increased land filling activities on both sides. However, at the moment there is no reliable reference or record of such activities, apart from the impact of the completed bank protection.

Bank protection structures affect channel morphology and dynamics, through restricting the width of wandering belts (Xu, 1997). The most active banks have been stabilised in the analysed river reach, especially in the Thai 


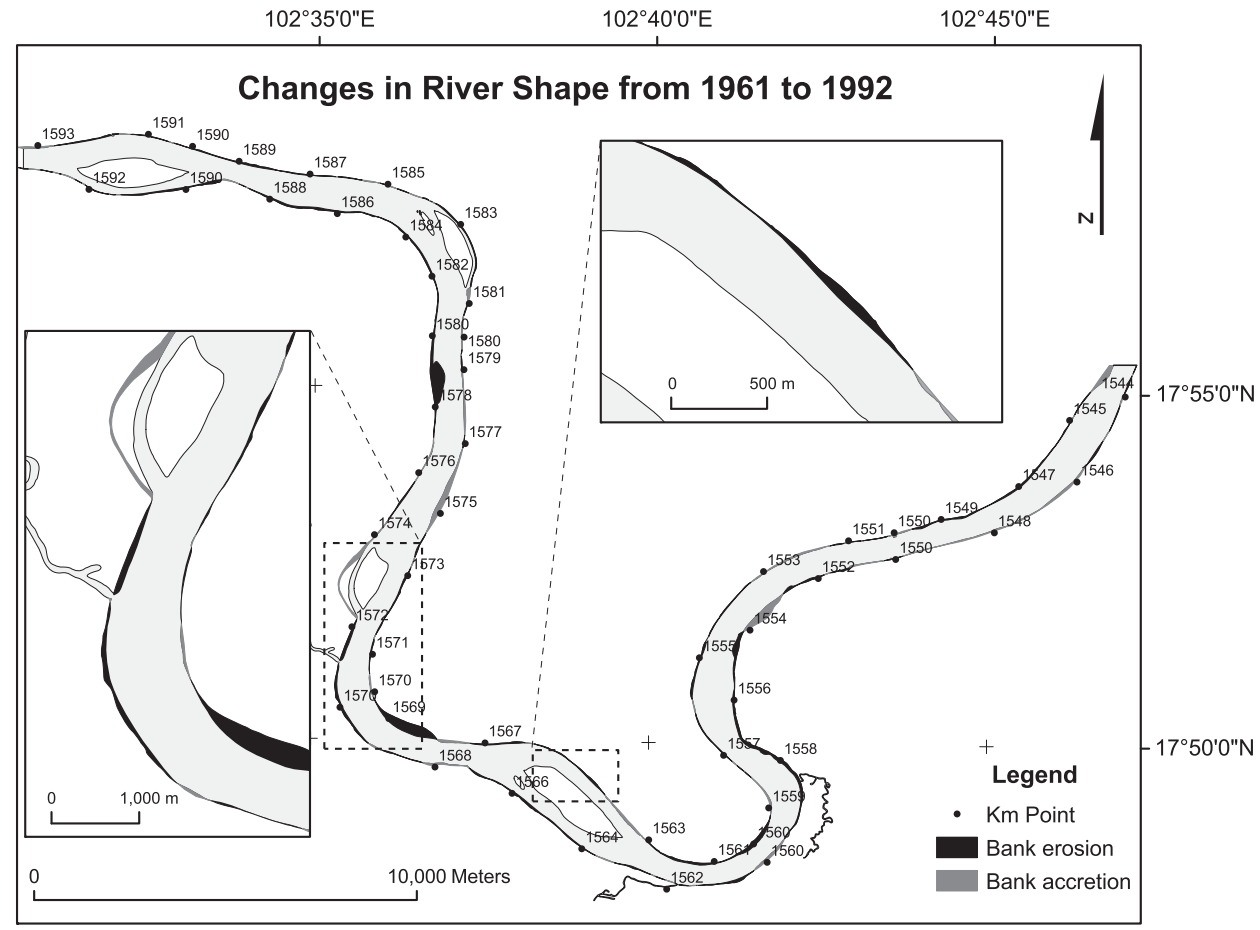

Fig. 6. Map of changes in riverbank location over time as a result of the comparison between bank locations of Hydrographic Atlases of 1961 and 1992.

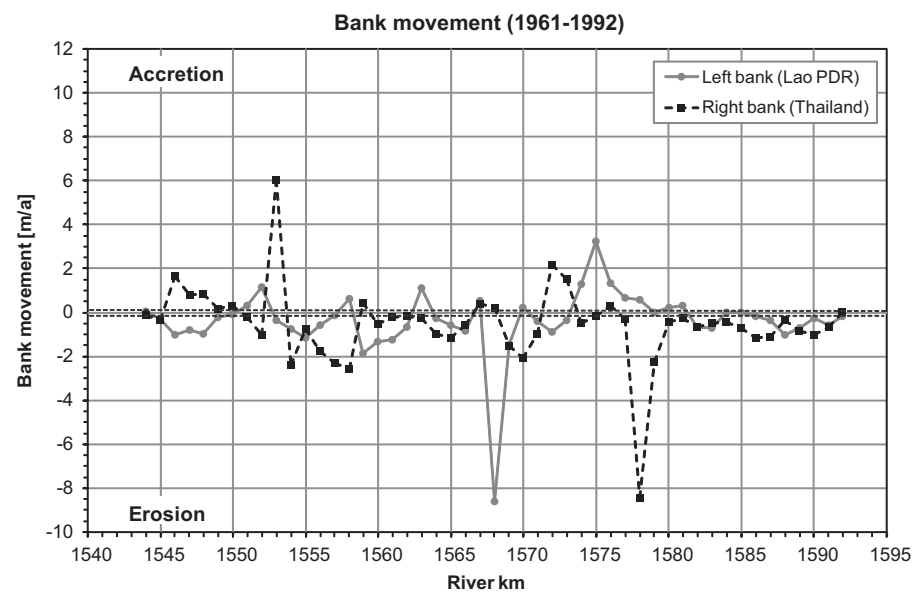

Fig. 7. The rates of bank movement (m/a) as a function of distance along each of the left and right banks between the years 1961 and 1992 . The horizontal dashed lines indicate the minimum level of bank movement that can be detected using the described methods.

side. The increased bank protection in the Thai side has decreased the erosion rates. In contrast, there are not many areas in the Lao side where the bank has been protected.
Bank protection increases the stress on the riverbed, which becomes more vulnerable than the protected riverbank. Thus, the bank protection structures play an important 


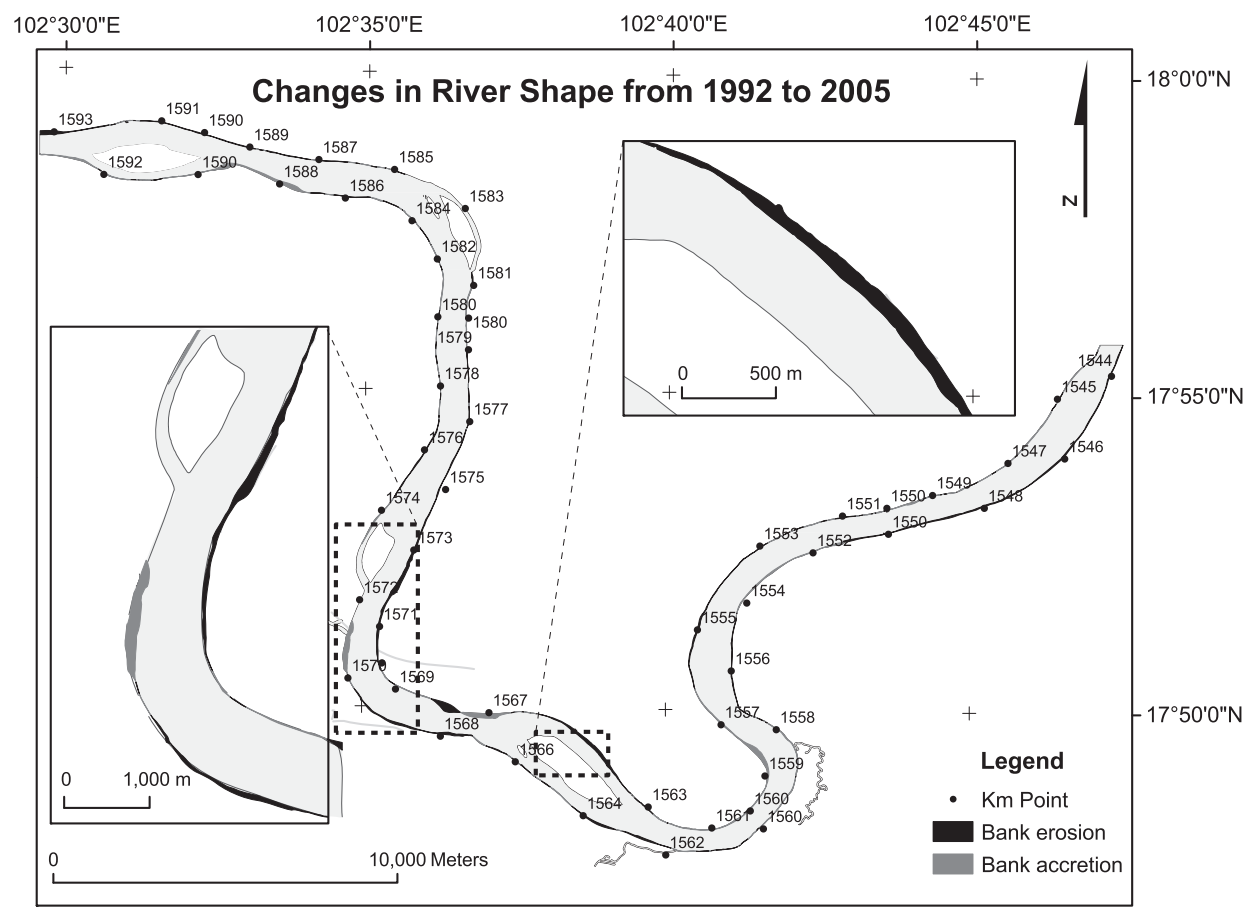

Fig. 8. Map of changes in riverbank location over time as a result of the comparison between bank locations of Hydrographic Atlas of 1992 and SPOT5 satellite images from $2004 / 2005$.

role in geomorphological changes such as deposition on flood plain, and erosion in the channel.

\subsection{Impact of hydrological regime changes}

Hydrologic changes in water and sediment discharge are the major contributing factors of hydraulic geometry change (Merritt and Wohl, 2003). Local communities and NGOs in the lower Mekong river have complained that the riverbank erosion (or collapse) were due to the water level fluctuation as a result of the upstream dams and rock blasting (World Rivers Review, 2001; Neave, 2002). For example, it was noted that the water level fluctuations have worsened since the blasting of reefs in 2001 as part of the navigation channel improvement project (SEARIN, 2003).

The annual medium and maximum water discharge have not experienced significant changes in Vientiane, apart from the sharp decrease in the discharge across all stations in 1992 when the Manwan Dam was closed for infilling (Adamson, 2006). In Chiang Saen, the water level fluctuations have been changed only in dry seasons. The water level fluctuations in wet season did not reveal any discernable differences between pre- and post-dam years, and appeared to be unaffected by the operation of the Manwan Dam (Lu and Siew, 2006; Lu et al., in press). The water level changes and fluctuation in the dry season would not cause frequent riverbank erosion compared to the same changes and fluctuations if in the wet season (Lu, 2006).

Therefore, the slight increase in the bank erosion over the latest period from 1992 to 2005 could be the consequence of the reduction of the suspended sediment concentration. The decrease in suspended sediment concentration in the lower Mekong River (Lu and Siew, 2006; Kummu and Varis, 2007) may increase erosional power or transport capacity (Brandt, 2000), and hence would eventually change the river's morphology. As sediment load has decreased, the river in the lower basin may increase its transport capacity (Friedman et al., 1998), and cause riverbank erosion. However, the decrease of suspended sediment rates in Nong Khai is not statistically significant (Kummu and Varis, 2007). The release of relatively sediment-starved, high energy water from the dams is likely to cause channel scouring and, possibly, coarsening of the bed material until equilibrium is reached and material cannot be moved by the flows (Batalla et al., 2004).

\section{Conclusions}

Many sites along the Mekong River were perceived as suffering from bank erosion problems that endanger 


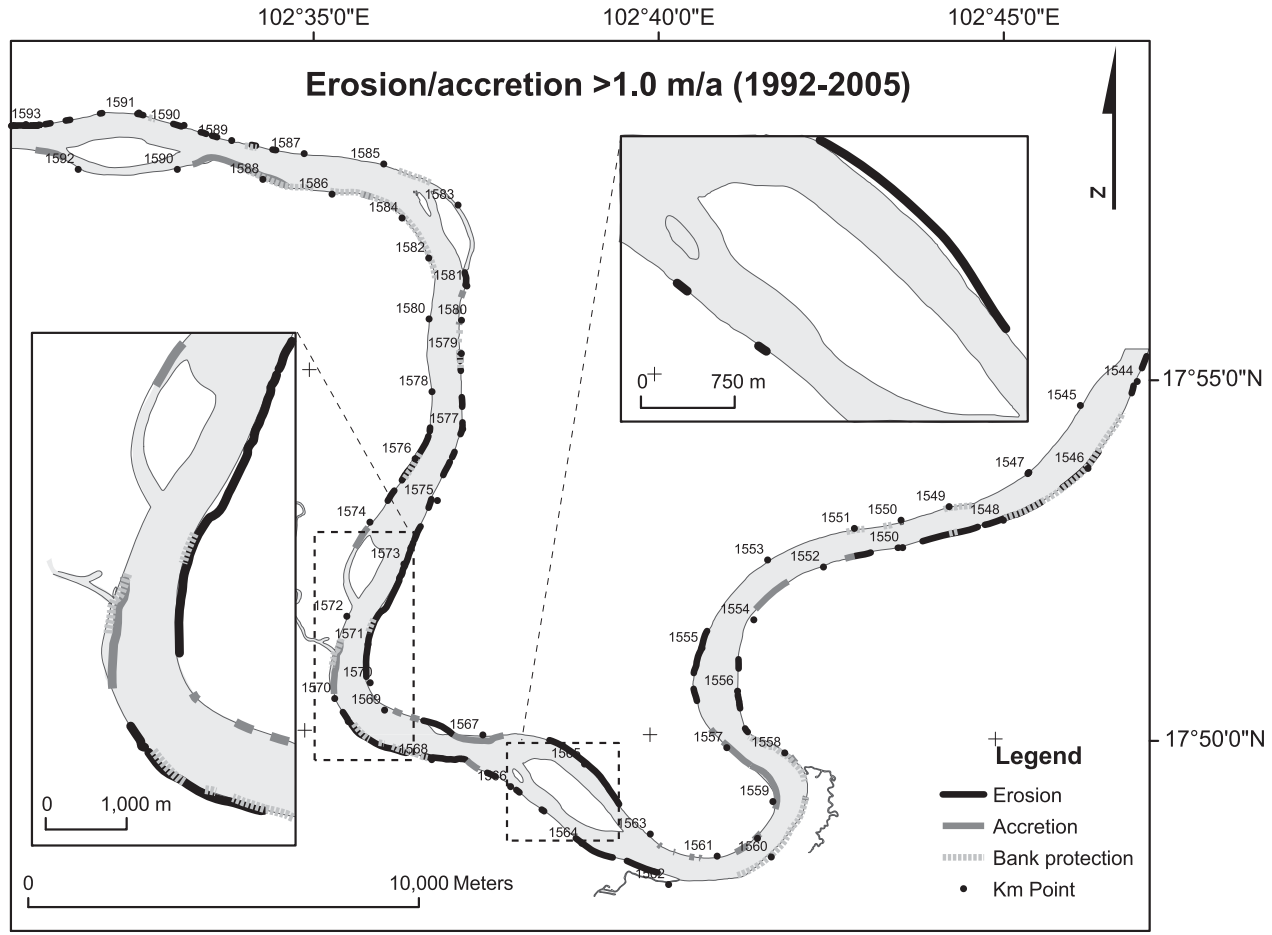

Fig. 9. Map of the riverbank location changes where the change in either direction has been more than $1.0 \mathrm{~m} / \mathrm{a}$ during the $1992-2005$, and bank protection locations as 2005 .

Table 2

Annual average island erosion and accretion rates $(\mathrm{m} / \mathrm{a})$ for the periods 1961-1992 and 1992-2005

\begin{tabular}{lll}
\hline & \multicolumn{2}{l}{ Annual bank movement (m/a) } \\
\cline { 2 - 3 } & $1961-1992$ & $1992-2005$ \\
\hline Erosion & 1.2 & 2.3 \\
Accretion & 0.3 & 3.2 \\
\hline
\end{tabular}

nearby settlements and infrastructures. Erosion in the Vientiane-Nong Khai section has been identified as a serious process area and a transboundary issue between Lao PDR and Thailand. This study assessed how much the shape of the river in Vientiane-Nong Khai area has changed over time by using the two Hydrographic Atlases of 1961 and 1992, derived originally from aerial photos and field survey, and two SPOT5 satellite image acquired on 4 December 2004 and 28 April 2005. Erosion and accretion rates on the left (Lao PDR) and right (Thailand) banks of the Mekong were analysed between two time periods: 1961-1992 and 1992-2005. Also, the possible causes of the bank erosion and accretion were discussed.
The bank erosion rates have been reported to be severe in the study section (JICA, 2004). However, the averaged rate for two sides along the studied section was not as severe as perceived. In fact, it was one order of magnitude lower compared to other large rivers of similar sizes. The quantified rates were 0.8 and $1.0 \mathrm{~m} / \mathrm{a}$ for the first and second analysis period, respectively, while the global average for a river of that size is $12.1 \mathrm{~m} / \mathrm{a}$ Van de Wiel (2003). The bank erosion rates in the islands were much higher compared to the ones along the riverbanks, being 2.4 and $4.8 \mathrm{~m} / \mathrm{a}$ for the two time periods analysed. The observed bank accretion was $0.4 \mathrm{~m} / \mathrm{a}$ during 1961-1992 and $0.7 \mathrm{~m} / \mathrm{a}$ during 1992-2005. Accretion rates in the islands increased from $0.6 \mathrm{~m} / \mathrm{a}$ during the first analysis period to $6.4 \mathrm{~m} / \mathrm{a}$ during the second one. The main reason for the increased accretion was the joining of one of the largest islands to the Lao PDR riverbank within the analysis period. The width of the Mekong in the study area varies from 600 to $1200 \mathrm{~m}$. Thus, the average annual erosion rate is $0.1 \%$ of the channel width, which is very low on a global scale.

Though the impact of bank erosion on humans has been perceived as a serious problem and its damages have been significant in the lower Mekong basin, the bank erosion 


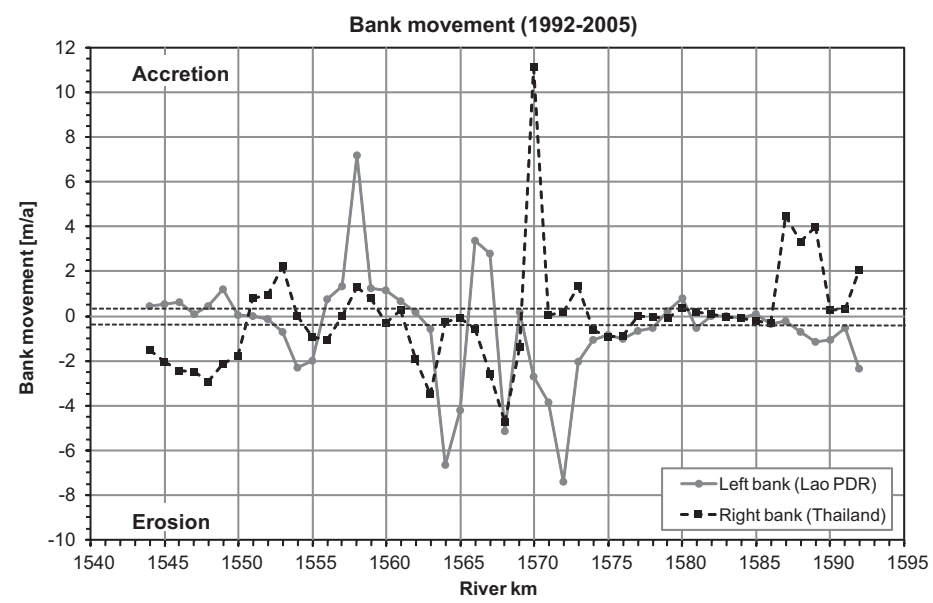

Fig. 10. The rates of bank movement $(\mathrm{m} / \mathrm{a})$ as a function of distance along each of the left and right banks between the years 1992 and 2005 . The horizontal dashed lines indicate the minimum level of bank movement that can be detected using the described methods.

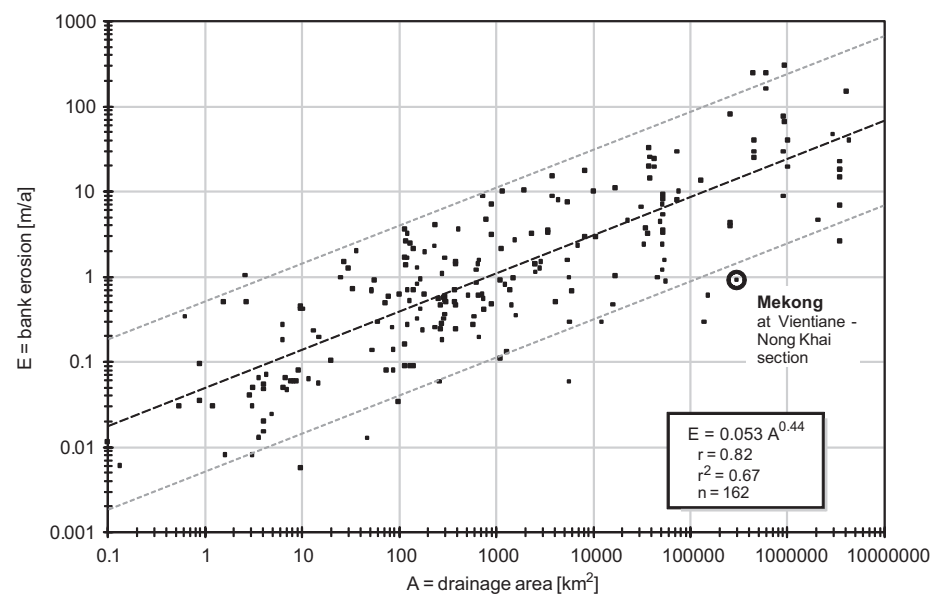

Fig. 11. Mekong study section bank erosion rate compared to global bank erosion database erosion rates where the data are taken from 221 observations from a wide range of rivers from around the world (Van de Wiel, 2003, 2007, personal communication).

rates are not excessive on a global scale. In this section the river is undergoing rather slow and localised rates of lateral channel migration, which happen to be impinging on a growing population and on land that is becoming increasingly valuable for economic development. Nevertheless, there is an urgent need to understand the underlying mechanisms. The bank erosion and channel change can also cause the change in the Thalweg line which is used as the border line between Thailand and Lao PDR. Therefore, it would be important to maintain the river channel stability through minimising the human impacts. Employing the historical maps and high-resolution images, we conclude that the riverbanks had experienced a slow to moderate erosion rate which could be the results of the construction interventions and possible sediment concentration changes. Such changes could be further enhanced in the region with the increasing changes in hydrodynamics as a result of human activities like reservoirs construction, river channel improvement for navigation, riverbank controls, bridge construction, and sand mining, etc. Work is proceeding to further examine some of these important impacts and to combine the 
modelled hydrodynamic and sediment transport processes with in-bank processes.

\section{Acknowledgements}

This work has been jointly funded by the Academy of Finland (under the project 111672), by the WUP-FIN project and by Sven Hallin Foundation. The authors are acknowledged to the Prasit Dimnivong, Keomany Luanglith, Phoumyenh Khounthikoumanne, and Sukkhawit Buaphuan. The staff from the Helsinki University of Technology, especially Dr. Olli Varis, Marko Keskinen, and Professors Tuomo Karvonen and Pertti Vakkilainen are equally acknowledged. The support of the Mekong River Commission is acknowledged. We thank also Dr. Steven Darby for his constructive comments and help which significantly improved the quality of this paper, as well as Dr. Marco Van de Wiel for his great help in global erosion rate information.

\section{References}

Adamson, P., 2006. An evaluation of landuse and climate change on the recent historical regime of the Mekong. Report produced for Mekong River Commission, 31pp.

Batalla, R.J., Gomez, C.M., Kondolf, G.M., 2004. Reservoir-induced hydrological changes in the Ebro River basin (NE Spain). Journal of Hydrology 290, 117-136.

Brandt, S.A., 2000. Prediction of downstream geomorphological changes after dam construction: a stream power approach. International Journal of Water Resources Development 16 (3), 343-367.

Campbell, I.C., 2005. Integrated water resources management for the Mekong River Basin. In: Biswas, A.K., Varis, O., Tortajada, C. (Eds.), Integrated Water Resources Management in South and South-East Asia. Oxford University Press, New Delhi, pp. 250-266.

Dury, G.H., 1969. GH relation of morphometry to runoff frequency. In: Chorley, R.J. (Ed.), Water, Earth and Man. Methuen, London, pp. $418-430$.

Friedman, J.M., Osterkamp, W.R., Scott, M.L., Auble, G.T., 1998. Downstream effects of dams on channel geometry and bottomland vegetation: regional patterns in the Great Plains. Wetlands 18, 619-633.

Fuller, I.C., Large, A.R.G., Milan, D.J., 2003. Quantifying channel development and sediment transfer following chute-off in a wandering gravel-bed river. Geomorphology 54, 307-323.

Grant, G.E., Schmidt, J.C., Lewis, S.L., 2003. A geological framework for interpreting downstream effects of dams on Rivers. In: O'Connor, J.E., Grant, G.E. (Eds.), A Peculiar River. American Geophysical Union, pp. 209-225.

Gupta, A., Liew, S.C., 2007. The Mekong from satellite imagery: a quick look at a large river. Geomorphology 85 (3-4), 259-274.

JICA, 2004. The study on Mekong Riverbank Protection around Vientiane Municipality in the Lao People's Democratic Republic. Interim Report, Japan International Cooperation Agency (JICA) and the Government of Lao P.D.R.

Kesel, R.H., 2003. Human modifications to the sediment regime of the Lower Mississippi River flood plain. Geomorphology 56, 325-334.

Kummu, M., Varis, O., 2007. Sediment-related impacts due to upstream reservoir trapping, the Lower Mekong River. Geomorphology 85, 275-293.

Lane, S.N., Richards, K.S., 1997. Linking river channel form and process: time, space and causality revisited. Earth Surface Processes and Landforms 22, 249-260.
Le, M.H., Tanaka, H., Tu, N.T., Viet, N.T., 2006. Prediction of river bank erosion in the lower Mekong river delta. Vietnam-Japan Estuary Workshop, 22-24 August, Hanoi, Vietnam.

Leopold, L., Wolman, M.G., 1957. River channel patterns: braided, meandering, straight. United States Geological Survey Professional Paper 282-B, 85pp.

Li, L.Q., Lu, X.X., Chen, Z., 2007. River channel change during the last 50 years in the middle Yangtze River: an example of the Jianli reach. Geomorphology (in press).

Lu, X.X., 2006. Transboundary environmental issues of the Mekong River: cooperation or conflicts among the riparian countries. In: Wong, J., Zou, K.Y., Zeng, H.Q. (Eds.), China-Asean Relations: Economic and Legal Dimensions. World Scientific, pp. 179-197.

Lu, X.X., Siew, R.Y., 2006. Water discharge and sediment flux changes in the Lower Mekong River: possible impacts of Chinese dams. Hydrology and Earth System Sciences 10, 181-195.

Lu, XX. Wang, J.J., Grundy-Warr, C., Poulsen, U. (in press). Are the Chinese dams blamed for the lower water levels in the Lower Mekong? In: Varis, O., Kummu, M., Keskinen, M. (Eds.), Modern Myths of the Mekong.

Mekong River Commission, 1961. Hydrographic atlas of 1961 for the Mekong. Surveyed in 1959-1961.

Mekong River Commission, 1992. Hydrographic atlas of 1992 for the Mekong. Surveyed by Department of Energy Development and Promotion, Thailand and Department of Communication, Lao PDR. Surveyed in 1989-1992, aerial photography in 1991/1992.

Mekong River Commission, 2003. State of the Basin Report: 2003, Mekong River Commission (MRC), Phnom Penh, 316pp. ISSN: 1728:3248.

Mekong River Commission, 2004. Databases of Mekong River Commission, Mekong River Commission, Phnom Penh, Cambodia.

Mekong River Commission, 2005. Overview of the hydrology of the Mekong Basin, Mekong River Commission, Vientiane, November 2005, 73pp.

Mekong River Commission, 2006. Spatial databases of Mekong River Commission. Mekong River Commission, Vientiane, Lao PDR.

Merritt, D.M., Wohl, E.E., 2003. Downstream hydraulic geometry and channel adjustment during a flood along an ephemeral, arid-region drainage. Geomorphology 52, 165-180.

MRC/WUP-FIN, 2006. Impact Assessment Report, WUP-FIN Phase II-Hydrological, Environmental and Socio-Economic Modelling Tools for the Lower Mekong Basin Impact Assessment. Mekong River Commission and Finnish Environment Institute Consultancy Consortium, Vientiane, Lao PDR, 282pp.

Nanson, G.C., Knighton, A.D., 1996. Anabranching rivers: their cause, character and classification. Earth Surface Processes and Landforms 21, 217-239.

Neave, M., 2002. Responses to feature on "potential physical and environmental impacts of dam building in the Lancang-Mekong Basin, Yunnan". Mekong Update and Dialogue 5 (3), 4-5.

Pham, B.V., Lam, D.N., Ho, D.D., 2004. Using remotely sensed data to detect changes of river bank in Mekong River, Vietnam, <http://www.gisdevelopment.net/application/natural_hazards/floods/ nhcy0009pf.htm $\rangle$.

Rinaldi, M., 2003. Recent channel adjustments in alluvial rivers of Tuscany, central Italy. Earth Surface Processes and Landforms 28, 587-608.

Rutherfurd, I., Bishop, P., Walker, M., Stensholt, B., 1996. Recent channel change in the Mekong River near Vientiane: implications for the border between Thailand and Lao PDR. In: Stensholt, B. (Ed.), Development Dilemmas in the Mekong Subregion: Workshop Proceedings, Melbourne, Australia.

SEARIN, 2003. Lancang Development in China: Downstream Perspectives from Thailand, Southeast Asia Rivers Network (SEARIN): $\langle$ http://www.searin.org $\rangle$.

Surian, N., 1999. Channel changes due to river regulation: the case of the Piave River, Italy. Earth Surface Processes and Landforms 24, 1135-1151. 
Surian, N., Rinaldi, M., 2003. Morphological response to river engineering and management in alluvial channels in Italy. Geomorphology 50, 307-326.

Van de Wiel, M.J., 2003. Numerical modelling of channel adjustment in alluvial meandering rivers with riparian vegetation. Ph.D. thesis, Department of Geography, University of Southampton.
World Rivers Review, 2001. Proposed Mekong Dam Scheme in China Threatens Millions in Downstream Countries, p. 5.

Xu, J.X., 1997. Evolution of mid-channel bars in a braided river and complex response to reservoir construction: an example from the middle Hanjiang River, China. Earth Surface Processes and Landforms 22, 953-965. 